\title{
Adipose derived stem cell based therapies or male/female pattern hair loss
}

\author{
Ryan A. Lockhart ${ }^{2}$, Cloe S. Hakakian ${ }^{2}$, Zoe E. Birnbaum ${ }^{2}$ and Joel A. Aronowitz ${ }^{1,2,3 *}$ \\ ${ }^{1}$ CedarsSinai Medical Center, Los Angeles, CA, USA \\ ${ }^{2}$ University Stem Cell Center, Los Angeles, CA, USA \\ ${ }^{3}$ USC Keck School of Medicine, Los Angeles, CA, USA
}

\section{Introduction}

In the United States, Alopecia Androgenetica, more commonly known as male or female pattern hair loss, affects approximately $50 \%$ of the male population and $45 \%$ of the female population $[1,2]$. Alopecia Androgenetica can be characterized by the gradual thinning of hair emphasized at the crown and frontal scalp, attributed to interactions among various genetic and endocrine factors [3,4]. Individuals impacted by Alopecia Androgenetica are subject to general psychological trauma, as many report a decreased quality of life, lack of self-confidence, and limited social contacts [4-6].

The hair growth cycle in the scalp is separated into 3 phases: anagen (growth), catagen (regression), and telogen (resting). The 26 year long anagen phase is classified as the growing period, whereas the catagen phase of regression lasts 23 weeks and is followed by a 12 week telogen resting phase [4]. Typical anagen to telogen ratio in an individual experiencing regular hair growth is established at 9:1 4. Individuals with Alopecia Androgenetica, however, experience a decrease in the duration of anagen phase as the hair cycle proceeds [4]. As the anagen phase decreases, the proportion of hair follicles in the telogen phase increases, inducing hair growth that is more fine [4]. Additionally, an increase in the turnover time between hair shedding and the anagen (growth) phase diminishes hair density at the scalp [4]. The degree to which individuals are affected by Alopecia Androgenetica is classified using the Norwood-Hamilton scale for men (Figure 1) [7], and the Savin scale for women (Figure 2) [8]. An alternative scale for females is the Ludwig scale, which is nearly identical to the Savin scale. These scales are based on standardized visual parameters and are often used to evaluate drugs in clinical hair growth studies [4]. Grade II on the

2

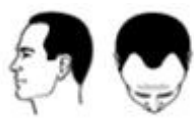

$3 \mathrm{~V}$

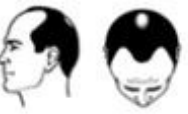

$5 \mathrm{~A}$

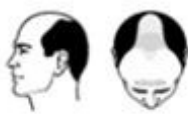

$2 A$

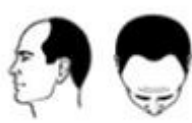

4

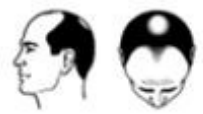

$5 \mathrm{~V}$

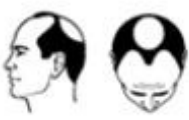

3

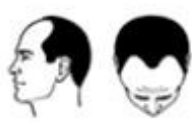

$4 \mathrm{~A}$

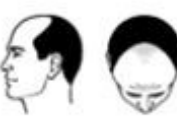

6

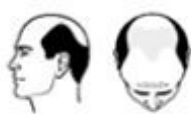

$3 \mathrm{~A}$

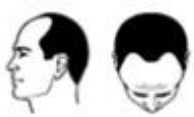

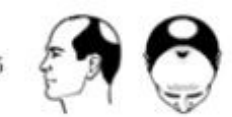

$-1$

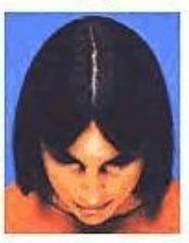

$1-4$

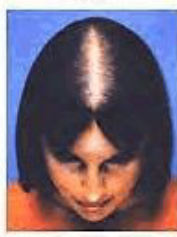

III

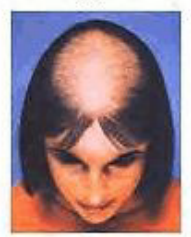

$\mathrm{I}-\mathbf{2}$

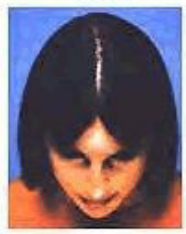

II-1

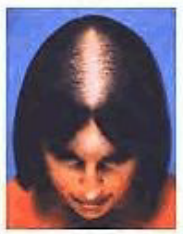

Advanced

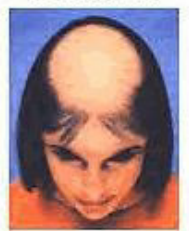

$1-3$

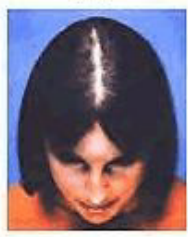

II-2

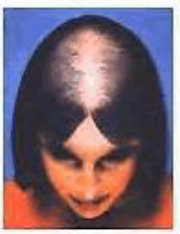

Frontal

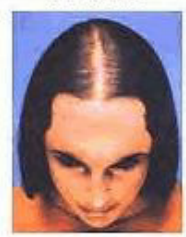

Figure 2. The Savin scale.

Correspondence to: Joel A. Aronowitz, CedarsSinai Medical Center, Los Angeles, CA, USA, E-mail: dra@aronowitzmd.com

Received: June 11, 2016; Accepted: July 11, 2016; Published: July 14, 2016 
Table 1. Summary of current treatment modalities.

\begin{tabular}{|c|c|c|c|c|}
\hline Treatment & Commercial Name & Mechanism of Action & Effect & Common Risks/Side Effects \\
\hline $\begin{array}{l}\text { Minoxidil } \\
\text { (topical) }\end{array}$ & Rogaine & Vasodilator & $\begin{array}{c}\text { Increased } \\
\text { anagen/telogen ratios } \\
\text { Increased follicle size } \\
\text { Increased hair count }\end{array}$ & $\begin{array}{l}\text { Skin rash and itching, } \\
\text { redness or flushing } \\
\text { Unwanted facial or } \\
\text { body hair }\end{array}$ \\
\hline $\begin{array}{l}\text { Finasteride } \\
\text { (oral) }\end{array}$ & Propecia & $\begin{array}{c}\text { Type II } 5 \mathrm{a} \\
\text { reductase inhibitor } \\
\text { Prevents conversion } \\
\text { of Testosterone into } \\
\text { DHT }\end{array}$ & $\begin{array}{l}\text { Increased hair count } \\
\text { Increase in hair } \\
\text { weight } \\
\text { Increased follicle } \\
\text { size }\end{array}$ & $\begin{array}{c}\text { NOT FOR USE IN } \\
\text { WOMEN may cause } \\
\text { birth defects } \\
\text { Altered Libido } \\
\text { Sexual Dysfunction } \\
\text { Impotence } \\
\text { Ejaculation Disorders } \\
\text { Breast enlargement } \\
\text { and/or tenderness }\end{array}$ \\
\hline $\begin{array}{l}\text { Dutasteride } \\
\text { (oral) }\end{array}$ & Avodart & $\begin{array}{c}\text { Type I and Type II } \\
\text { 5areductase } \\
\text { inhibitor } \\
\text { Prevents conversion } \\
\text { of Testosterone into } \\
\text { DHT }\end{array}$ & $\begin{array}{l}\text { Increased hair count } \\
\text { Increase in hair } \\
\text { weight } \\
\text { Increased follicle } \\
\text { size }\end{array}$ & $\begin{array}{c}\text { NOT FOR USE IN } \\
\text { WOMEN may cause } \\
\text { birth defects } \\
\text { Altered Libido } \\
\text { Sexual dysfunction } \\
\text { Impotence } \\
\text { Ejaculation Disorders } \\
\text { Breast enlargement and/or } \\
\text { tenderness }\end{array}$ \\
\hline $\begin{array}{c}\text { Follicular Unit } \\
\text { Extraction } \\
\text { (FUE) }\end{array}$ & $\begin{array}{c}\text { Hair } \\
\text { Transplant }\end{array}$ & $\begin{array}{l}\text { Hair follicles are } \\
\text { physically } \\
\text { transplanted from } \\
\text { one area to another }\end{array}$ & $\begin{array}{l}\text { Redistributes hair } \\
\text { follicles }\end{array}$ & $\begin{array}{l}\text { Donor site morbidity } \\
\text { Hair follicles may not } \\
\quad \text { survive transfer }\end{array}$ \\
\hline
\end{tabular}

requires application to treatment areas twice a day, and must be used consistently before results are seen within the first 46 months. Maximum remedial effects are established at 12 years, at which point hair counts plateau, and hair density quickly returns to baseline values in the event that treatment is discontinued [4]. Oral Finasteride, a synthetic azosteroid, acts as a 5alphareductase inhibitor that prevents conversion of testosterone to dihydrotestosterone (DHT) [4]. Oral Finasteride must be taken consistently and indefinitely as progressive balding will be induced once treatment comes to a halt. Negative side effects of oral Finasteride include decreased Prostate Specific Antigen (PSA), libido and ejaculate volume, as well as erectile dysfunction [4]. When ingested for longer than 2 years, oral Finasteride is not shown to facilitate continued hair growth, but results were maintained at 5 years (longest reported follow up) [4]. Additionally, Finasteride is only prescribed for male patients as it has shown limited efficacy in women and may cause birth defects in pregnant women. Dutasteride, commercially available as Avodart, is a 5alphareductase inhibitor used to treat enlarged prostates, similar to Finasteride which is also used by some for treatment of male pattern baldness, but has similar efficacy to Finasteride and is again not recommended for use by women. While finasteride and dutasteride are not indicated for use in women, come offlabel studies have shown efficacy at higher doses [10-14]. Efficacy results for finasteride and dutasteride are conflicting across different studies, with some showing efficacy and others not. Apart from topical Minoxidil, oral Dutasteride and oral Finasteride, the current state of the art non pharmaceutical method is the Follicular Unit Extraction (FUE), more commonly known as a hair transplant, which can be costly and result in noticeable donor sites. Additionally, there is a risk that the transplanted hairs will not take to the donor site and will die off shortly after transplant. New therapies that are more effective, have fewer side effects and are applicable to the female patient population are needed.

\section{Adipose tissue, adipose derived stem cells and hair growth}

There is growing evidence supporting a relationship between dermal adipose deposits and proper follicle function. A variety of studies have shown in mice that a reduction of intradermal adipose tissue has been associated with abnormalities in skin structure including hair loss, epidermal hyperplasia and abnormal sebaceous gland function [15-17]. A 2011 study by Festa et al. examined the role of intradermal adipocytes on follicular stem cell activity [18]. They observed a dynamic process of adipogenesis that parallels the activation of hair follicle stem cells. Additional functional analysis revealed that immature adipocyte cells are necessary and sufficient to drive follicular stem cell activation and they attributed this relationship to the production of plateletderived growth factor (PDGF) by immature adipocyte lineage cells. They ultimately established that adipose tissue plays a crucial role in the normal hair cycle and even went as far as to suggest that telogen may be the result of a localized absence of adipose tissue.

A 2013 study by He et al. examined the involvement of adiposederived stem cells in the hair cycle [19]. Male athymic nude mice received injections of CD34+, CD34or unsorted CD34+ and CD34SVF cells derived from adipose of GFP transgenic mice. All injections were composed of $1 \times 10^{6}$ cells combined with fetal epidermal and dermal 
cells. Mice were analyzed 3 weeks after implantation occurred. After 3 weeks, Hu et al. noted that there were larger tissue blocks and more hair follicles formed in the CD34+ group compared to the other two groups. Histological analysis revealed that GFP-tagged CD34+ cells actually participate in the formation of hair follicles, blood vessels, and fat tissue.

The combined findings of Festa et al. and He et al. suggest a strong relationship between adipose, adipose-derived stem cells and the hair growth cycle. The findings suggest that both adipose and adiposederived stem cells have a potential therapeutic application for hair growth which deserves further exploration.

\section{Adiposederived stem cells: A promising future for hair loss}

Adiposederived stem cells (ASCs) are of increasing interest in the treatment of Alopecia Androgenetica. Adiposederived stem cells are being explored for a variety of regenerative applications based on their ability to differentiate down a variety of cellular pathways as well as the regenerative benefits afforded by the growth factors produced [2022]. A variety of studies have been published examining the effects of adiposederived stem cells and therapies based on adiposederived stem cells, such as cellassisted lipotransfer (CAL) or adiposederived stem cell conditioned media (ADSCCM), in relation to the reversal of male and female pattern hair loss. The early results published are promising.

ADSCCM is the growth factor rich media produced when adiposederived stem cells are cultured. During culturing, the ASCs constantly release growth factors into the surrounding culture media. The ASCs are subsequently removed, leaving a cellfree, growth factor rich solution which has been shown to exhibit regenerative potential similar to treatment using adiposederived stem cells. The culture conditions alter the growth factor content, with lower oxygen being associated with enhanced regenerative potential [23].

An early study conducted by Won et al. published in 2010 examined the effect of ASCs and ADSCCM on hair growth in mice [24]. They began by examining the effect of ADSCCM on human dermal papilla cells (hDPCs) and immortalized keratinocyte cells (HaCaT cells) in vitro. ADSCCM was shown to significantly enhance the proliferation of both HaCaT cells and hDPCs. Next, cell cycle analysis was conducted on ADSCCM treated hDPCs. They noted increased proliferation of hDPCs as a result of ADSCCM exposure, which they attributed to enhanced activation of Erk and Akt signaling pathways. The Erk pathway has been associated with mitogenesis and the Akt pathway mediates cell survival signals, and both have been associated with enhanced survival and proliferation of hDPCs $[25,26]$. With the promising results afforded by the early stages of this study, they then examined the effect of ADSCCM on hair shaft elongation in 5 male volunteers. Intact hair follicles were extracted and cultured with ADSCCM, minoxidil or nothing added (control). The ADSCCM treated follicles elongated by $40 \%$ compared to the control group, similar to those in the minoxidil group. The final facet of this study examined in vivo effects. 48 mice received injections of PBS or $5 \times$ $10^{5}$ ASCs every 3 days for 9 days. Concurrently, ADSCCM or control media was topically applied. They noted that in mice who received ASC injections that there was earlier conversion of telogen to anagen. Additionally, after 4 weeks they noted significantly accelerated hair growth and increased number of hair follicles after topical application of ADSCCM.

Another 2010 study by Park et al. reported on the effects of ADSC-
CM [27]. They examined the effects of ADSCCM produced under normoxic conditions (NorCM) and hypoxic conditions (HypoCM). In culture experiments using hDPC and human epidermal keratinocytes (HEKs), they noted that ADSCCM exposure increased proliferation of hDPCs and HEKs in a dose dependent manner. When comparing hypoCM and norCM, no significant difference was observed in $\mathrm{hDPF}$ proliferation but hypoCM showed a significant increase in HEK proliferation compared to norCM treatment. This study also examined the effects of norCM and hypoCM in a mouse model $(n=21)$. Mice received 3 subcutaneous injections of $100 \mathrm{ul}$ of control media $(n=5)$, norCM $(n=5)$ or hypoCM $(n=5)$ at 3 day intervals. Overall, they noted that mice treated with hypoCM induced the anagen phase and the development of dark spots (hair growth) on treated mice more rapidly than the norCM treated mice.

Another study published in 2013 by Jeong et al. [28] examined differences between various preparations of ASCs and ADSCCM (with and without UVB irradiation preconditioning) and their effect on hair growth in mice. Telogen matched mice were shaved and injected with ASCs or ADSCCM with and without UVB irradiation (four groups total). Mice received injections of $1 \times 10^{4}$ cells into the dermis of a shaved area or 50ul of ADSCCM injected into the dermis of the shaved area. Overall, they noted that all groups were able to convert telogen to anagen, but both the ASC and ADSCCM groups which had been preconditioned with UVB irradiation demonstrated accelerated conversion and subsequently more hair growth

In 2015, Shin et al. published a retrospective clinical case series on the use of ASCs and ADSCCM for the treatment of female pattern hair loss [29]. Treatment was administered under a 12 week protocol where subjects received ADSCCM applications once per week with a micro needling roller. 27 women with hair loss classified as Ludwig I were treated with ADSCCM and all completed the 12 week treatment course. Hair density and thickness were assessed using phototrichogram captures. They reported an increase in mean hair density from 105.4 hairs $/ \mathrm{cm}^{2}$ to 122.7 hairs $/ \mathrm{cm}^{2}$, which represented a $16.4 \%$ increase. These reports are similar to those reported using topical minoxidil twice daily for 48 weeks, which reported $17.3 \%$ and $13.8 \%$ increase in hair density using $5 \%$ and $2 \%$ minoxidil, respectively [30]. Additionally, as a result of 12 week ADSCCM application, mean hair thickness increased from $57.5 \mathrm{um}$ to $64.0 \mathrm{um}$, an $11.3 \%$ increased. In terms of hair thickness, ADSCCM was shown to be superior to reported outcomes of $2 \%$ minoxidil (5.0\% at 24 weeks) [10]. No serious adverse events were associated with the treatment. The study lacks significant long term followup data, as a majority of subjects were followed only for the 12 week course of treatment, but clinical benefit was maintained in all patients who were followed up for 6 month $(n=9)$.

In 2012, Fukuoka et al. [31] published their reports using ADSCCM for hair loss in 24 patients (12 men, 12 female) with androgenetic alopecia. Subjects received ADSCCM injections 46 times every 35 weeks. The authors reported overwhelmingly favorable results in terms of patient and investigator satisfaction and reported that all treated patients demonstrated increased hair growth. The study lacks quantifiable data in terms of hair density and thickness.

As a followup to their 2012 study, Fukuoka and Suga once again reported [32] favorable outcomes using ADSCCM in 2015. 22 patients (11 male, 11 female) received intradermal injections of ADSCCM every 35 weeks for a total of 6 sessions. Trichogram captures were taken before treatment and 13 months after the last treatment session. Overall, they noted a significant increase in the number of hairs in both 
male and female patients. Male patients showed an average increase of $29 \pm 4.1$ hairs $/ \mathrm{cm}^{2}$ and female patients showed an average increase of $15.6 \pm 4.2$ hairs $/ \mathrm{cm}^{2} .6$ out of 11 males were concurrently taking Finasteride during the course of treatment. No significant difference was observed in the amount of hair growth observed between men with and without finasteride use. Another group of 10 patients $(8$ male, 2 female) were treated in a sidebyside fashion, were the left half of the scalp received ADSCCM and the right side received saline placebo injections. Surprisingly, increases in hair growth were seen in both sides of the scalp as a result of treatment, but the ADSCCM treated side was significantly higher than the saline only side of the scalp. This suggests that mechanical tissue injury could possibly result in marginal hair growth or that the effects of the ADSCCM are not entirely localized to the treatment area, but rather can affect the whole scalp via local circulation.

\section{Clinical trials currently underway}

The potential for applications of adipose and adiposederived stem cell based therapies looks promising. While ADSCCM and ASCbased therapies are commercially available in some countries, larger, controlled clinical trials are needed to formally establish safety and efficacy of these therapies. There are currently 4 studies listed on Clinicaltrials.gov for the treatment os Alopecia Androgenetica using an ASC based therapy. A phase 3 study (Identifier: NCT02594046) beginning in October 2015 is examining the effects of ADSCCM and is listed under the name "The Effect of Allogeneic Human Adipose Derived Stem Cell Component Extract on Androgenic Alopecia” [33]. CAL is currently under investigation in the STYLE Trial [34] sponsored by Kerastem Technologies, LLC. This Phase II study which began in November 2015 (Identifier: NCT02503852) is investigating the uses of a combination of fat grafting prepared using the Puregraft system (Puregraft, LLC) and adiposederived regenerative cells (ADRCs) isolated using the Cytori Celution 800/CRS system. Another Phase I clinical trial using the GID SVF2 device to isolate stromal vascular fraction cells is currently recruiting (identifier: NCT02626780) for a trial titled "Adiposederived SVF for Treatment of Alopecia" and is currently recruiting as of December 2015 [35]. The trial does not involve fat grafting, only injections of freshly harvested SVF cells. A second Phase 0 study with similar methodology (Identifier: NCT02729415) listed under the name "PointofCare Adiposederived Cells for Hair Growth (ASVF2016)" is set to begin recruiting in July 2016 [36].

\section{Conclusion}

The body of evidence in favor of the use of adiposederived stem cells and ASCbased therapies for male/female pattern hair loss is steadily growing. These therapies offer the benefit of reduced side effects compared to the current treatment modalities and appear to be effective in both males and females. With relatively no new formally approved treatments for hair loss in the last $20+$ years, the future of hair restoration may lie in adiposederived stem cell based therapies.

\section{References}

1. Shin H, Ryu HH, Kwon O, Park BS3, Jo SJ (2015) Clinical use of conditioned media of adipose tissue-derived stem cells in female pattern hair loss: a retrospective case series study. Int J Dermatol 54: 730-735. [Crossref]

2. Olsen EA (2001) Female Pattern Hair Loss. J Am Acad Dermatol 46: 70-80.

3. Dinh QQ, Sinclair R (2007) Female pattern hair loss: current treatment concepts. Clin Interv Aging 2: 189-199.

4. Otberg N, Finner AM, Shapiro J (2007) Androgenetic alopecia. Endocrinol Metab Clin North Am36: 379-398.[Crossref]
5. Cash TF, Price VH, Savin RC (1992) Psychological Effects of Androgenetic Alopecia on Women: Comparisons with Balding Men and with Female Control Subjects. $J$ Am Acad Dermatol 29: 568 $\neg 575$.[Crossref]

6. Van Neste DJ, Rushton DH (1997) Hair problems in women. Clin Dermatol 15: 113125.[Crossref]

7. The American Hair Loss Association. "The Norwood $\neg$ Hamilton Scale." 2004 $\neg 2010$ http://www.americanhairloss.org/men_hair_loss/the_norwood_scale.asp.

8. The American Hair Loss Association. "Degree of Hair Loss." 2004-2010. http://www. americanhairloss.org/women_hair_loss/degree_of_hair_loss.asp

9. Krupa SD, Chakravarthi M, Shilpakar R (2009) Male androgenetic alopecia population-based study in 1,005 subjects. Int J Trichology 1: 131-133.[Crossref]

10. Price VH, Menefee E (1990) Quantitative estimation of hair growth. I. androgenetic alopecia in women: effect of minoxidil. J Invest Dermatol 95: 683-687.[Crossref]

11. Levy LL, Emer JJ (2013) Female pattern alopecia: current perspectives. Int J Womens Health 5: 541-556.[Crossref]

12. Trüeb RM; Swiss Trichology Study Group (2004) Finasteride treatment of patterned hair loss in normoandrogenic postmenopausal women. Dermatology 209: 202-207. [Crossref]

13. Olszewska M, Rudnicka L (2005) Effective treatment of female androgenic alopecia with dutasteride. J Drugs Dermatol 4: 637-640.[Crossref]

14. Moftah N, Moftah N, Abd-Elaziz G, Ahmed N, Hamed Y, et al. (2013) Mesotherapy using dutasteride-containing preparation in treatment of female pattern hair loss: photographic, morphometric and ultrustructural evaluation. J Eur Acad Dermatol Venereol 27: 686-693.[Crossref]

15. Chen HC, Smith SJ, Tow B, Elias PM, Farese RV Jr (2002) Leptin modulates the effects of acyl CoA:diacylglycerol acyltransferase deficiency on murine fur and sebaceous glands. J Clin Invest 109: 175-181.

16. Herrmann T, van der Hoeven F, Grone HJ, Stewart AF, Langbein L, et al. (2003) Mice with targeted disruption of the fatty acid transport protein 4 (Fatp 4, Slc27a4) gene show features of lethal restrictive dermopathy. J Cell Biol 161: 1105-1115.[Crossref]

17. Jong MC, Gijbels MJ, Dahlmans VE, Gorp PJ, Koopman SJ, et al. (1998) Hyperlipidemia and cutaneous abnormalities in transgenic mice overexpressing human apolipoprotein C1. J Clin Invest 101: 145-152.[Crossref]

18. Festa E, Fretz J, Berry R, Schmidt B, Rodeheffer M, et al. (2011) Adipocyte lineage cells contribute to the skin stem cell niche to drive hair cycling. Cell 146: 761-771. [Crossref]

19. He J, Duan H, Xiong Y, Zhang W, Zhou G, et al. (2013) Participation of CD34-enriched mouse adipose cells in hair morphogenesis. Mol Med Rep 7: 1111-1116.[Crossref]

20. Zuk PA, Zhu M, Mizuno H, Huang J, Futrell JW, et al. (2001) Multilineage cells from human adipose tissue: implications for cell-based therapies. Tissue Eng 7: 211-228. [Crossref]

21. Planat-Benard V, Silvestre JS, Cousin B, André M, Nibbelink M, et al. (2004) Plasticity of human adipose lineage cells towards endothelial cells: physiological and therapeutic perspectives. Circulation 109: 656 $\neg 663$.[Crossref]

22. Rehman J, Traktuev D, Li J, Merfeld-Clauss S, Temm-Grove CJ, et al. (2004) Secretion of angiogenic and antiapoptotic factors by human adipose stromal cells. Circulation 109: 1292-1298.[Crossref]

23. Frazier TP, Gimble JM, Kheterpal I, Rowan BG (2013) Impact of low oxygen on the secretome of human adipose-derived stromal/stem cell primary cultures. Biochimie 95 : 2286-2296.[Crossref]

24. Won CH, Yoo HG, Kwon OS, Sung MY, Kang YJ, et al. (2010) Hair growth promoting effects of adipose tissue-derived stem cells. J Dermatol Sci57: 134-137.[Crossref]

25. Robinson MJ, Cobb MH (1997) Mitogen-activated protein kinase pathways. Curr Opin Cell Biol 9: 180-186.[Crossref]

26. Tang Y, Zhou H, Chen A, Pittman RN, Field J (2000) The Akt proto-oncogene links Ras to Pak and cell survival signals.J Biol Chem 275: 9106-9109.[Crossref]

27. Park BS, Kim WS, Choi JS, Kim HK, Won JH, et al. (2010) Hair growth stimulated by conditioned medium of adipose-derived stem cells is enhanced by hypoxia: evidence of increased growth factor secretion. Biomed Res 31:27-34.[Crossref]

28. Jeong YM, Sung YK, Kim WK, Kim JH, Kwack MH, et al. (2013) Ultraviolet B preconditioning enhances the hair growth-promoting effects of adipose-derived stem cells via generation of reactive oxygen species. Stem Cells Dev 22: 158-168.[Crossref] 
29. Shin H, Ryu HH, Kwon O, Park BS3, Jo SJ (2015) Clinical use of conditioned media of adipose tissue-derived stem cells in female pattern hair loss: a retrospective case series study. Int J Dermatol 54: 730-735.[Crossref]

30. Lucky AW, Piacquadio DJ, Ditre CM, Dunlap F, Kantor I, et al. (2004) A randomized, placebo-controlled trial of $5 \%$ and $2 \%$ topical minoxidil solutions in the treatment of female pattern hair loss. J Am Acad Dermatol 50: 541-553.[Crossref]

31. Fukuoka H, Suga H, Narita K, Watanabe R, Shintani S (2012) The latest advance in hair regeneration therapy using proteins secreted by adipose $\neg$ derived stem cells. $A m J$ Cosmet Surg 29: 273-282.

32. Fukuoka H, Suga H (2015) Hair Regeneration Treatment Using Adipose-Derived Stem Cell Conditioned Medium: Follow-up With Trichograms. Eplasty 15: e10.[Crossref]
33. The effect of Allogeneic Human Adipose Derived Stem Cell Component Extract on Androgenic Alopecia. https://clinicaltrials.gov/ct2/show/NCT02594046. Accessed: June 3, 2016

34. STYLE A Trial of Cell Enriched Adipose For Androgenetic Alopecia (STYLE). https:// clinicaltrials.gov/ct2/show $/$ NCT02503852?term $=$ STYLE\&rank=3. Accessed: June 3 , 2016

35. Adiposederived SVF for Treatment of Alopecia. https://clinicaltrials.gov/ct2/show/ NCT02626780?term $=$ Adiposederived $+\mathrm{SVF}+$ for + Treatment + of + Alopecia\&rank $=1$. Accessed: June 3, 2016

36. PointofCare Adiposederived Cells for Hair Growth (ASVF2016). https:/ clinicaltrials.gov/ct2/show/NCT02729415?term=Adiposederived $+\mathrm{SVF}+$ for + Treat ment + of + Alopecia\&rank $=2$. Accessed: June 3, 2016

Copyright: @2016 Lockhart RA. This is an open-access article distributed under the terms of the Creative Commons Attribution License, which permits unrestricted use, distribution, and reproduction in any medium, provided the original author and source are credited. 